Никола Божиловић

Универзитет у Нишу

Филозофски факултет

E-mail: nikola.bozilovic@filfak.ni.ac.rs
УДК 316.7316 .77659 .2

Преїледни рад

Текст примљен: 28.06.2015.

\title{
КОМУНИКАЦИЈА ПОПУЛАРНОГ
}

Сажетак. Чланак је йосвећен йроблемима комуникације йойуларне кулииуре. Он се односи на уже значење йойуларне кулйуре. Оно обухвайа йревасходно дела умейничких форми која имају йойуларан каракӣер - лако разумљиве и забавне садржаје

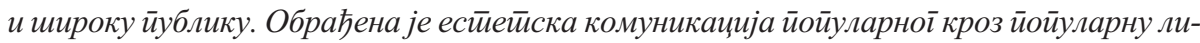
йерайуру, филм, йой и рок музику. Рад је йодељен на йри дела. Први део йосвећен је естиетиици комуникације йойуларне кулииуре. У њему се врии анализа йлавних формално-естиейских йосйуйака уірађених у сииваралачки израз йойуларноі. У делу који је йосвећен сочијалним асиекіиима комуникације йойуларне умейностии, размайрају се индустиријски, ииржишни и комерцијални иринцийи на којима је саздана чийава ова кулйура. То је време нових йехнолоіија и масовне йойрошње, које су, йо речима Ерика Хобсбаума, „кулитурни иејзаж“ који је ирроменио начин доживљавана умейничкой од сииране нове йублике. На крају, размайрају се звезде йойуларне кулйуре, као комуникайори. Ауйор их додаје као нову, чак кључну, карику у већ йознайом ланиу комуникације коїа чине ауйор, дело и йублика. Звезде (билма, йойуларне музике) јесу акйивни факитори комуникације и њени носиоци. Оне су йосреднищи йреко којих йублика усйостиавља односе са ауйорима (йисцима, режскерима, комйозийорима) и делима у којима се теие звезде йојављују. Звезде као „нови олимйијции“ (Морен) јесу још једна значајна кайеі̄орија која комуникацију йойуларне кулйуре чини особеном.

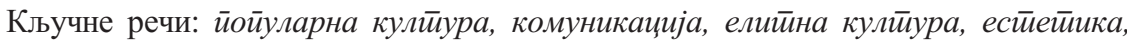
кулитурна индустирија, ӣот̄рошачко друшӣво, звезде.

\section{Увод}

Многи социолози не би се сложили са тезом да у склопу одређења комуникације дела популарне културе/уметности ${ }^{1}$ треба уважити и њихову естетску

\footnotetext{
* Припремљено у оквиру пројекта Центра за социолошка истраживања Филозофског факултета у Нишу, Традиција, модернизащија и национални иденииииеете у Србији и на Балкану у йроцесу евройских иниееірација (179074), који финансира Министарство за просвету и науку Републике Србије.

1 „Популарна култура укључује најшири могући дијапазон појава: праксе свакодневног живота, радничку и омладинску поткултуру, медијску културу (филм, телевизија, интернет), животне стилове, облике забаве, популарну музику, потрошачку културу итд“ (Đorđević, 2012: 27-28).
} 
димензију. Они би се радије бавили компонентама које се могу „измерити“ и нумерички изразити. Међутим, упркос важности чињеница и емпиријских података, анкетоманија, статистичарење и „лудило бројки“ илити квантофренија (P. Sorokin) могу заклонити унутрашње и деликатне квалитативне везе које се тичу односа (популарне) уметности и друштвене праксе. Позитивизам огољених чињеница добрано се увукао у социологију претећи да угуши ону танану, највиталнију сферу духа која одређује смисао друштвеног битисања. Реч је, наравно, о култури, о њеној значењској улози, симболичком карактеру и вредносном смислу. Естетски смисао стваралаштва представља интегрални део свих области стваралаштва у култури. Због комуникацијске природе уметничких дела изражене у способности да изазову одобравање или одбацивање, идентификацију или отпор, она више од било чега другог припадају области културе (Kon, 2001: 6).

Популарна и масовна култура располажу својим естетским принципима који су код њих добили су сопствени садржај, смисао и значај - прилагодили се околностима и ситуацији (пост)модерног света. У социологији културе, комуникација се кроз питања укуса посматра као естетски чин, а кроз питања стила као социјални догађај, при чему се ове компоненте схватају у њиховом дијалектичком јединству. С једне стране, комуникацијом се култивише („васпитава“) или срозава естетски укус, а с друге стране комуницирање је процес путем кога се врше разматрања стилских тенденција у уметности. И најважније: кроз популарну културу, њен уметнички израз и начин њене комуникације с публиком рефлектују се облици моћи и подрећености, власти и покоравања, доминације (хегемоније) и отпора (Gramši, 2012; Fisk, 2001).

\section{Естетика комуникације популарне културе}

Хијерархизација културних облика данас није тако изражена као некада, али се није сасвим изгубила. Хијерархијски концепт културе у својој основи има класни карактер (Bauman, 1973: 13), а по истом принципу и према одговарајућим културним обрасцима врши се и слојевање укуса на нижи, средњи и високи ниво (Shils, 1961; Bourdieu, 1984; Gans, 1999). Раздеоба културе по принципу естетске вредности је условна и има релациони карактер. Појам популарне културе подразумева нешто што му је опозитно, а то је култура која се руководи највишим смисловима. На два супротна пола вредносне скале култу-

Овај чланак односи се на уже значење популарне културе које обухвата превасходно дела умейничких форми које имају популаран карактер (литература, филм, поп и рок музика) - дакле, реч је о експлицитно естетској комуникацији популарног. 
ре најчешће се налазе појмови елитног и популарног - један подразумева други, први се дефинише помоћу (или наспрам) другог и обратно. Осим што има историјски, социјални и релациони карактер, популарна култура је у свом појму вишеструко амбивалентна: она јесте део уметности, али њени садржаји стоје наспрам високе уметности, она је укорењена међу млађом генерацијом, али то није пресудно за одређење њене посебности, тржишно је оријентисана, али не значи да је мотивација економске исплативости у корену њеног постојања. Комплексност конотација појма „популарна култура“ огледа се у разноврсности и разноликости његових форми, садржаја и културних порука (Жикић, 2012: 319).

Популарна култура у својим почецима (позоришни комади, забавни паркови, коњске трке, бокс мечеви, циркуске забаве, маскараде, багателе, кабаретске преставе, варијетеи, водвиљи, новински фељтони) стављана је у знатно нижи ранг од оног на коме су била дела елитне илити „озбиљне“ културе. Реч је о раздобљу које обухвата период од средине XVIII века и траје у XIX веку, када долази до социјалних померања која се тичу, превасходно, читалачке публике (урбанизација, индустријализација, повећање писмености). Тада у Енглеској долази до „све већег популарног занимања за читање“, пише Јан Вот (Watt). Пораст читалачке публике има да захвали променама у структури средње клаce, која није имала новца за скупоцена издања те се задовољавала много јефтинијим формама забавног штива, као што су баладе, памфлети и новине у којима су се штампале кратке приче, односно романи у наставцима (Vot, 1990: 223). Осим занимања за популарну романескну форму, публика коју су чинили представници ниже средње класе интересовала се и за друге приредбе које су имале забаван и сензационалистички карактер. Та публика представљала је важну коцкицу у друштвеном мозаику тога доба, а њене културне потребе одговарале су одређеној социјалној и економској ситуацији.

„Турнири, краљевске прославе, религијске процесије или националне комеморације представљали су спектакуларне манифестације које су изазивале осећања, градиле убеђења, каналисале емоције и, укратко, ткале друштвене односе“ (Kon, 2001: 7).

Данас је читава област културе заражена „вирусом“ популарног, али у позитивном смислу: савремена култура обраћа се свима, а не само уском кругу поштовалаца одређене уметности, преноси се преко медија, своје формалне уметничке поступке прилагођава актуелном а не идеалном реципијенту, укида демаркациону линију између уметника и публике, премешта уметност из гале- 
рија на улицу, износи је из замрачених дворана на светлост свакодневног живота. Захваљујући алтернативном уметничком изразу, који има карактер демократског и популарног, рођена је нова естетика и поетика уметничке алтернативе - улично позориште, хепенинг, перформанс, стрит-арт, поп и видео арт, графити (Dragićević Šešić, 2012). Нови уметнички израз био је праћен одговарајућим сензибилитетом, што ће рећи другачијим односом према стварности, природи, човеку, окружењу. Мада је у сфери популарне културе било много посртања, поједностављивања, уметничких падова и пропалих пројеката, постоји обиље филмова, музичких композиција и видео-спотова, стрипова, инсталација, плаката и других облика визуелног стваралаштва који су ушли у цивилизацијски незаборав.

Одређени елементи, некад резервисани за елитну културу, захваљујући тржишту прешли су у сферу популарне културе и постали свима доступни. Данас је дошло до својеврсне симбиозе елитног и популарног у култури, чиме су оригинална дела врхунског естетског квалитета, поставши својина популарне култуpe, променила значења. Онтологија естетике популарних форми добија друштвени смисао тек у процесу комуникације, а та комуникацијска раван уметности оправдава и сам чин уметничког стварања. Ако је за „праву“ уметност важило правило да постаје витална тек када почне да комуницира, популарна уметност је коперниканским обртом редефинисала овај принцип: она је настала баш зато да би комуницирала! Дела популарне уметности су већ у моменту свог настанка комуникативна будући да изван комуникације она немају други ваљани разлог постојања. Подразумева се да је комуникација данас медијски посредована. „Комуницирам, дакле постојим“ - пише Франсис Бал (Balle), парафразирајући познату Декартову (Descartes) максиму која се тицала процеса мишљења (Bal, 1997: 92).

Формално-естетски поступци у делима популарне уметности нису, као у елитној уметности, херметични, тј. затворени у љуштури самодовољних форми, при чему се та дела по потреби дају на општење уском кругу образованих. Популарна дела не опште у специјалним тренуцима, на само за то одређеним местима, нити само са уским кругом образованих. Она су у сваком моменту приступачна најширим слојевима публике и тичу се живота у свакодневљу. Ђило Дорфлес (Dorfles) je, не мислећи ни на једну уметност посебно већ на уметност у начелу, пледирао да уметничка дела заправо не постоје док не уђу у процес комуникације, то јест општења са публиком.

„Умјетност која ће остати у ембрионалном стању неизражености и бити умјетност само за онога који ју је зачео, никад неће постићи пуну аутентичност“" (Dorfles, 1963: 107). 
Далеко смо од примисли да је тзв. елитна култура изгубила сопство, још мање да је она нестала у таласима популарне културе. Једно је ипак извесно: граница између ових културних области данас је много лабавија него некада 2 . Популарна култура је чак помогла високој култури да изађе из свога забрана и „посвећености“, да уклони светачку ауру и прихвати одређене елементе језика популарних форми културе, те тако постане свима доступна. Речју, популарна култура пружила је могућност делима високих уметничких вредности да буду комуникативнија тако што ће своје поруке приближити ширим круговима публике. Уметнички садржаји и поруке популарног, исказани кроз шлагер и спортску манифестацију, филмску гротеску и љубавни роман, плес и тобоган у луна-парку, другачије су врсте од оних којима се бави уобичајена естетика. Оне су упућене „просечном човеку“, „необразованом“ примаоцу, и желе успех у свакодневици - то су уметности за модерно индустријско друштво. Масовна култура дефинише се као супротност високој култури, „озбиљна уметност“ конституише се ограђивањем од масовне. Међутим, по Каспару Мазеу (Мааse), суштинску разлику између озбиљне и забавне уметности уопште не треба тражити у делима. Не одлучује естетска теорија о томе који је начин рецепције примерен ком делу него би пре требало поћи од различитих начина у којима људи стичу естетска искуства (Maze, 2008: 20-21).

Садржаји популарне културе ближи су данашњим конзументима зато што су прилагођени духу епохе, интересовањима већине и начину рецепције од стране савремених прималаца уметничких порука. Књижевна дела постају „филмична“, преузимајући манире филмскога ритма и монтаже, озбиљна музика се аранжира и изводи у џез или рок аранжманима, а многа сликарска дела приближавају се форми поп-арта. За разлику од дела високе уметности која су се могла разумевати и тумачити на начин који је институционализован, усвојен превасходно у школама, популарна култура комуницира мање обавезујућу, али лако препознатљиву и схватљиву форму, проширујући на тај начин круг оних који су у стању да одговоре на такву комуникацију. Компетенција за то не мора да зависи од нивоа формалног образовања, већ се она ствара учествовањем у самој комуникацији која се остварује кроз популарну културу (Жикић, 2012: 336).

Технички проналасци и капиталистичке тежње за комерцијализацијом довеле су до промене односа према уметности као таквој и, нарочито, до великих промена на плану уметничке комуникације. Доведени су у питање принципи је-

${ }^{2}$ Никад није разјашњено да ли квалитетан бестселер треба схватити као роман предодређен за популарност у коме се користе неке учене стратегије, или као учени роман који из неког тајанственог разлога постаје популаран“ (Eko, 2002: 200). 
динствености, оригиналности и непоновљивости, који су задуго представљали суштину уметничких поступака. Техничке могућности репродукције уметничких дела чиниле су да је оно што се почетком прошлога века у уметности сматрало „високим“ и било намењено елити, приближило конзументу, тј. постало приступачно ширим слојевима публике (Benjamin, 1974). Превасходно због тога је граница између високе и популарне културе сасвим избледела ${ }^{3}$. Тај процес, започет још у модерни са масовном производњом, почео је обилато да се користи у постмодерним стратегијама. Постмодерна „метода играња са формама популарног и узвишеног“ састоји се у томе да се поједини текст популарног карактера (роман, филм, музика, стрип) исприча кроз стилска решења високе уметности, а да при том његов садржај тематизује веома комплексна питања. На тај начин је постмодерно дело, кроз читање првог и другог нивоа, постало доступно широким масама, а опет, у њему није био повређен укус елитног реципијента који има моћ препознавања поступака који су некад припадали елитној уметности (Maširević, 2011: 205).

Напред изречено не треба разумети тако да је популарна култура данас постала узор високој култури. Напротив. И даље остају замерке да је популарна култура у начелу пасивна и конформистичка, да не поставља питања и да у већини случајева није захтевна. Међутим, у пољу те културе (у литератури, сликарству, музици, филму) има активности и авангардности у односу на ставове према виталним темама друштвеног живота. Ако се зна да популарна култура није монолитна, онда може као на длану бити јасно да се, рецимо, рок музика генерално бави аутентичним облицима друштвених промена, побуне и слободе, док поп остаје мек, тривијалан и површан. У највреднијим делима популарне уметности постоји јединство естетског и симболичког интереса јер је њен карактер садржан не само у естетским него и у социјално-комуникацијским елементима. Једноставност и непосредност уметничког израза производи снажне и искрене доживљајне реакције, па се зато у делима популарне уметности може произвести осећај узвишености и одушевљења једнако снажан као и онај произведен у класичном уметничком стваралаштву (Božilović, 2014: 51). У овој области стваралаштва реципијент (гледалац, слушалац, читалац) се пише великим словом јер је он једнак по важности (ако не и више од тога) од аутора или извођача 4 .

3 „Свакодневно искуство уживања није битно различито од онога што се дешава у сусрету с великом уметношћу“ (Maze, 2008: 21).

4 Чини ми се згодним да овде изнесем искуство Слободана Јовановића, везано за српског књижевног критичара Богдана Поповића. Иако овде постоји анегдотска форма казивања, испричани догађај је упечатљив, додуше индиректно, за проблем популарне уметности и однос реципијената 
Како се развијао однос између елитне и популарне културе? Поп је напредовао у изражајном смислу управо тако што је следио путеве озбиљних уметничких форми, посебно у периоду од средине шездесетих година минулог века. У почетку је то радио подражавајући високе естетске норме и узусе, а затим је покушавао да у одређеним жанровима и сам компликује своју естетску структуру. Мноштво филмова, стихова битничке поезије, дела тзв. џинс литературе, уметничких плаката из доба психоделичне музике, те композиције прогресивног и арт-рока представљају еклатантне примере високог естетског нивоа културе која носи предзнак популарног. То је било време алтернативног погледа на свет у коме су се супкултурне вредности почеле јасно издвајати из „стрејт друштва“, афирмишући неконвенционалне видове физичког и сензуалног представљања. Нарочиту пажњу у том смислу привлачи музички жанр који је од стране музичке штампе и публике (ретко самих извођача) назван прогресивни рок или кратко „прог“ (у својим раним видовима познат и као „андерграунд“ музика). Аутори и извођачи прога у свом музицирању одступали су од комерцијалног поп модела, стварајући под утицајем џез импровизација или барокне свите повезаних тема (Macan, 1997: 168). У ту сврху биле су прихваћене инструменталне и техничке иновације из музичких сфера изван рока. Коришћење флауте, концертног клавира, виолина, чембала, чела, акустичне гитаре са дванаест жица или дувачке секције давало је снимцима „симфонијски“, оркестарски, фолклорни или пасторални призвук. Пинк Флојд (Pink Floyd), Hajc (Nice), Прокол Харум (Procol Harum) и, потом, „други талас“ извођача прога Џенесис (Genesis), Jec (Yes), Емерсон, Лејк и Палмер (Emerson, Lake and Palmer), постигли су велики комерцијални успех, упркос концептуалном и експерименталном приступу композицији, звучној палети и извођењу. Комуникациja је била успешна без обзира на удаљавање од конвенција поп сингла, гитарског рока и идиома заснованих на блузу. Музичка виртуозност, комплексност и ,уметничка форма“ прога били су усаглашени са његовим друштвеним контекстом пошто знатан проценат фанова и музичара овога жанра, понајвише

\footnotetext{
према њеним садржајима. Елем, Богдан је пролазећи поред једне каванице у предграђу приметио некаквог носача како „сав премире“ слушајући циганску музику. У исти мах он се упитао какве разлике има између тога носача који ужива у циганској музици и њега, Богдана, који ужива у Бетовену. По чему су уживања једног љубитеља Бетовена узвишенија од уживања једног човека из народа који ужива слушајући цигански мелос? Укратко, закључак је да су осећања оног носача по својој искрености била једнако естетска, вредна колико и нечија осећања на Бетовеновом концерту, а ако би се гледало на њихову јачину, може бити да су била чак интензивнија (Јовановић, 2005: 134).
} 
британских, потиче из средње класе и образован је у приватним школама, универзитетима и уметничким колеџима (Bortvik i Moj, 2010: 78-79).

Социолошки аспекти комуникације популарне уметности постају, ван сваке сумње, комплетни увођењем у игру и њених естетских компоненти. Социјална комуникација популарног у великој мери изводи се из односа популарног и елитног као естетски узорног ${ }^{5}$. Та комуникација није непосредна као у елитној култури/уметности, већ је медијски посредована и зависи од низа техничких чинилаца (филмови, грамофонске плоче, компакт дискови, телевизија). Нема ничег популарног што данас није прошло кроз медије ${ }^{6}$. Дела популарне културе комуницирају са милионском, а не са одабраном (елитном, високозахтевном) публиком. Зато она морају да задовоље најважније критеријуме популарног, као што су забава, лакоћа, пријемчивост. То не значи да излазе из оквира естетског, већ само то да им естетско није примарни циљ. У комбинацији естетског и забавног очитују се особености комуникације популарне културе, која је демократичнија и прихватљивија широким слојевима публике. Зато ову културу вребају две опасности: ако њени производи буду тешко разумљиви, то ће угрозити њихову популарност; уколико, пак, комуницирају само преко тривијалних и лакомислећих садржаја, њихово трајање биће кратко и сасвим ограничено у времену.

Поставља се питање зашто је данас висока култура устукнула пред налетом популарне културе. По мишљењу већине социолога XX века о популарној култури, разлози за то су врло једноставни и могу се сублимирати у следећем: Дела популарне културе се сама нуде, она вас просто опседају на сваком кораку, најављују се разнобојним и шареним плакатима, висе на киосцима попут кобасица, чујете их са звучника које не видите. Популарна култура вас умирује и одвраћа пажњу од животних тешкоћа. Њена дела не захтевају од вас ништа осим жеље да им се придружите. Она ће вам обезбедити задовољство без готово икаквог интелектуалног напора. Представљају сажвакану храну коју треба

5 „Естетика, теорија и критика уметности обухватају низ проблема чија анализа прекорачује компетенције социолога. Али, социолог је обавезан да узме у обзир резултате тих анализа. То се односи првенствено на конструкцију уметничког дела, његове формалне одлике, врсту и естетску конвенцију, фонд естетичких појмова, на критеријум естетских оцена који примењују зналци уметности“ (Kloskovska, 2001: 244).

${ }^{6}$ Уз обилату помоћ медија, популарна култура узела је под своје и политику, тако да на власти опстају махом популисти - они политичари који лакомисленим и неодговорним изјавама изазивају код грађана тренутно олакшање и стварају катарзу. Њихове изјаве су попут лаких нота популарне музике, које одлазе у заборав после неколико слушања. 
само прогутати. Укратко, садржаји популарне културе су лаки, привлачни, занимљиви, угодни и неоптерећујући. С друге стране, за садржајима високе културе морате трагати, а за њихово разумевање морате уложити знатан интелектуални напор; та култура је озбиљна, бескомпромисна, тешка и захтевна.

Постоји уврежено мишљење да дела популарне културе не настају са примарно естетским циљем, већ да она удовољавају много профанијим захтевима, као што су „убијање“ времена и бег из досаде (sic). Арнолд Хаузер (Hauser) каже да је управо досада извор популарне уметности. Ово треба прихватити са резервом јер потребе за забавом, разонодом и опуштањем не настају само из досаде. Из оваквог схватања произлази да је популарна уметност само „бедни надоместак за празнину“, који је чини „забавном, лакомисленом и лаком“ (Наuser, 1986: 115). Постоји вероватније социолошко објашњење настанка популарне уметности. Наиме, почетком XIX века дошло је и до великог пораста доколице, посебно „женске“, коју је омогућила једна важна економска промена. Старе домаће кућне обавезе престале су јер се већина потребних предмета почела производити у мануфактурама и могла се купити у радњама. Вишак слободног времена утицао је да се оно утроши на рецепцију популарних садржаја културе (Vot, 1990: 225). У поређењу са данашњим временом масовна публика коју су интересовали садржаји популарне културе тога доба била је кудикамо малобројнија. При том, примећује Мазе, модерна масовна култура надовезала се на популарне разоноде прединдустријске епохе. Револуционарне промене у сфери рада и слободног времена обликовале су продор у свет масовног слободног времена и културне индустрије, а све то било је омогућено процесима индустријализације и конкурентске привреде, као и животом у градовима који су брзо расли преласком милиона људи на рад у фабрике. Новине у сфери рада у двадесетом веку, попут увођења осмочасовног радног времена, довеле су до „омасовљења“ слободног времена и свеукупног замаха масовне културе. У друштвеним променама дошло је до раздвајања посла и слободног времена, што је указивало на „изузетан добитак слободе“. Све у свему, тенденција је била јасна: међу животним циљевима незаустављиво је расла важност слободног времена и његовог задовољавања (Vidi Maze, 2008: 25-31). То је нарочито дошло до изражаја после другог светског рата, када масовна култура, захваљујући расту техничких могућности, куповне моћи и повећању слободног времена, постаје „општа култура“, тј. култура заједничка свим слојевима. У периоду поп-арта 60-их долази до највећег апсурда у историји популарне културе - њене елитизације, омогућене креативном разменом с високим уметностима.

Питања неких теоретичара, попут оног зашто популарна уметност потиче на пасивност и самодопадљивост уместо на активност и критику, захтевају из- 
лазак из оквира естетике и разматрање скупа друштвених околности које представљају спољни оквир уметничких посртања. Као и много пута пре тога, естетичка питања траже социолошке одговоре. Нарочито у домену популарне културе.

\section{Социјални аспекти комуникације популарног}

За социолошко објашњење комуникације популарних дела културе потребно је да се, осим естетских компоненти, анализује њен индустријски и тржишни карактер. Нема ту никавог антагонизма јер су у карактер културе индустријског друштва уграђени и одговарајући естетски принципи преко којих она комуницира са публиком. Комуникација популарног дефинише се у корелацији са иниееракцијом, будући да публика са својим укусима одређује избор садржаја и формалних поступака у креирању дела популарне културе. Због тога је комуникација популарних дела културе различита од комуникације „уметничке“ културе. Овде се рачуна са масовношћу и хетерогеношћу публике по различитим основима - класном, расном, етничком, националном, родном, полном, професионалном, резиденцијалном, конфесионалном и, нарочито, генерацијском. Непобитно је да је узрасна група конзумената важна зато што млади чине највећи број корисника производа популарне културе.

У наизглед неприродној симбиози, с једне стране естетског, а с друге индустријског и тржишног, долази до новог начина комуницирања, а са тим и до другачијих типова публике, нових културних потреба и промена у сфери укуса. У сфери популарне културе снажно долази до изражаја њена комерцијална страна, која је нарочито транспарентна у поп музици. Код ње се има посла са економским појмовима - тржишта, инвестиција, рентабилности, куповине, новца, рекламе, продаје. Овде се мора споменути и улога продуцента који је истовремено и по потреби и саветник, и финансијер, и реализатор. Сматра се да је рок, у односу на поп, независнији и резистентији према законима тржишта, међутим ни он не измиче законима економије. Анри Торг (Torgue) пише о карикатуралном парадоксу поп и рок музичара, илуструјући га случајевима у којима они на сцени из свег грла поручују да новац квари све, а при том добро напуне своје џепове. Укратко, та музика је неизоставно, по својој природи, комерцијална (Vidi Torg, 2002: 89-92).

Друштвено-економски миље припремио је терен за популарну културу, чији је прави процват започео у времену у коме је спрега нове технологије и масовне потрошње створила, по речима Ерика Хобсбаума (Hobsbawm), „општи културни пејзаж“. Развојем друштва у коме је једна технички индустрија- 
лизована привреда преплавила наше животе културном производњом мноштва звукова, слика, речи и симбола, у потпуности се променио начин доживљавања уметничког стваралаштва. Индустријска револуција која је захватила целокупну област културе догодила се и у подручју и производима свести. Технички прогрес заменио је ручне вештине и створио услове за настанак нових изражајних форми и достигнућа, од којих је највеће и најоригиналније кинематографиja (Hobsbaum, 2014: 9). Филмско доба довело је до доминације слике: покретна слика је револуционисала и све друге уметности, почевши од ликовних уметности до архитектуре, књижевности, поезије и музике. Савремено друштво постаје продукт визуелне опсервације и конструкције, као што и свет популарне културе, већ од средине прошлога века, функционише по принципу покретних слика (Fulkinjoni, 1980).

Жестоки критичари културне индустрије Адорно (Adorno) и Хоркхајмер (Horkheimer) писали су у Дијалекӣици ӥросвейиӣељьӣва (Dialektik der Aufkldrung, 1947) да је њено одлучивање о потрошачима посредовано забавом. Културна индустрија као „предузеће за забаву“ захваћена је „одозго“ и доведена „на висину времена““. Она је довела до радикалних промена културног живота.

„Културна индустрија може да се похвали да је одлучно спровела често неспретну транспозицију културе у сферу потрошње, да је то уздигла у принцип, ослободила забаву наметљивих наивности и поправила квалитет робе. Што је постајала моћнија, што је неумољивије терала сваког аутсајдера било у пропаст било у синдикат, то је бивала све финија и узвишенија све док се коначно није закључила синтезом Бетовена и Касино де Париа. Њена је победа двострука: оно што споља брише као истину може унутра бескрајно да репродукује као лаж“ (Adorno i Horkhajmer, 2012: 77).

Масовна производња, поглавито од средине XX века, подстиче непрекидни ланац масовне потрошње. Индустријализација свести доводи до преокретања вредносних критеријума, тржишни принципи постају важнији од естетских, а новац постаје еталон за све друге вредности. Тај систем у коме бледи граница између масовног и популарног данас је апсолутно усавршен. Горан Гоцић пише да масовном производњом и механичком репродукцијом култура у тржишту добија „егзактни кванититативни критеријум“. Тријумф прагматистичког материјализма изражен је у могућности да се свака вредност изрази тржишно и да сваки културни производ има свој новчани еквивалент. Стање у 
култури доведено је до апсурда, по коме никакав артефакт не може да тражи квалитативну вредност све док не нађе тржишну. А када је пронађе, свака друга вредност постаје му излишна (Vidi Gocić, 2012: 40-42).

Популарна култура не може се у целости идентификовати са потрошачком културом (пост)индустријског друштва. Али, модерно друштво које преферира потрошњу као основни друштвени однос у сваком случају било је плодно тле за настанак и развој популарног као забавног, хедонистичког и спектакуларног. Епоха масовне потрошње започела је од средине XX века, а пун замах потрошачке културе долази са неолибералним моделом капитализма и настанком $x u$ йерӣойрошачко̄ друштва (Lipovetsky, 2008). Конзумеризам тада постаје начин живота у правом смислу јер захвата тоталитет друштвено-економског и културног живота. У тим условима свет добија „филмско“ убрзање. Популарна култура преузима примат на пољу културе јер својим садржајима успева да одговори на захтеве и брзину живота у друштву коме је потрошња постала примарни циљ.

У друштву које преферира спектакл, небично и изузетно, грандиозно и упечатљиво, и култура је морала добити одговарајаће особине. Иако у популарном изразу има много тога артистичког, он је ипак у целини наглашено спектакуларан. Спектакл је утемељен на јаким ефектима и заносу, који скупа омогућују бекство из стварности и стварају утеху. Његова привлачност проистиче превасходно из његове визуелне снаге и способности да задржи поглед посматрача (Vukadinović, 2013: 71). Када се зна да се у данашњој глобалној култури реч све више повлачи пред сликом (Hobsbaum, 2014: 21), онда култура спектакла постаје начин живота савременог човека. Друштво спектакла међу првима је антиципирао Ги Дебор/Debord (La Sociŭtŭ du spectacle, 1967), пишући о кризи модерног капитализма кога је он сматрао друштвом у коме доминирају слике и у коме је потрошња централна преокупација. Живот у том друштву представљен је као огромна акумулација призора. Све што је некада било непосредно доживљавано сада је удаљено у представу. „Спектакл није само скуп слика“, пише Дебор и поентира: „То је друштвени однос између људи посредован сликама“ (Debor, 2003: 6). Лаж се сада сели из поља тривијалне наративности у бескрајно поље визуелних утисака.

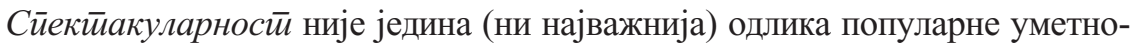
сти, али она има битну улогу у комуникацији са публиком. Она најчешће иде у пару са забавом. Популарна уметност данас дели судбину медијске културе будући да се већина њених садржаја пласира или преноси преко медија. Најзначајнији елемент популарне културе као дела медијске културе заснован је на спектаклу, а идеја забаве лежи у корену спектакуларне представе. Штавише, за- 
бава данас чини окосницу свакодневног живота и она се са културе шири и на домен политике, економије, спорта, па чак и науке. Естетика забаве веома често налази се у близини кича, у коме је појавно постало важније од суштинског. Ово се односи на америчку културу са које су се забава и спектакл преселили у све кутке земљине кугле. Популарност лаких и тривијалних садржаја произлази из принципа хедонистичког задовољства које се схвата као последица драстичних промена културних вредности у светским размерама и стварања новог типа личности. Нова потрошачка етика названа је „етика задовољства“ или „етика забаве“. Она се супротставља некадашњој „етици рада“, као што се хедонизам супротставља аскетизму. Некадашњи морални квалитети, који су приписивани култури карактера, бивају замењени омиљеношћу и дивљењем, повезаним са културом личности (Gronow, 2000: 22). Ерго, данас се сви културни производи у свету вреднују у односу на забавне параметре, а личностима и догађајима приступа се првенствено са аспекта забаве.

„Показатељ да забава преовлађује у друштву јесте чињеница да озбиљна литература, уметност, озбиљне идеје и људи не добијају пажњу и поштовање, зато што се нигде не уважава нечији истински допринос већ искључиво забавна вредност (...) Можемо рећи да доминација културе забаве представља глобални феномен који прецизно одсликава дух времена у коме живимо“(Vukadinović, 2013: 102-103).

Тачно је да уметничка дела не постоје (само) ради тога да би забављала људе, али је такође тачно да забавно у уметности није идентично кичу. Бројни су примери дела „озбиљне“ уметности и литературе која својим садржајима побуђују пажњу великог броја реципијената, док је у популарној уметности то готово постало правило. У времену свега глобалног: трговине, политике, науке и комуникација, и култура се глобализовала, а њене поделе постале су сасвим условне и релативне. Писци високог реномеа, попут Балзака (H. de Balzac), Игоа (V. Hugo), Дикенса (C. Dickens), Вилијамса (T. Williams) или Хемингвеја (E. Hemingway), читају се у једном даху јер озбиљне теме „доносе“ на, могло би се рећи, популаран начин. Многи од њих су у свом времену, укључујући и Шекспира (W. Shakespeare), сматрани писцима за широке читалачке масе, док су тек накнадно њихова дела сврставана у „озбиљну“ уметност. Исто важи и за филмске величине типа Фелинија (F. Fellini), Буњуела (L. Buñuel), Форда (J. Ford) или Тарантина (Q. Tarantino), чија дела комуницирају са публиком упркос својој естетској високозахтевности. Од виртуоза из света класичне музике који су велику популарност стекли, између осталог, обрадом познатих поп и 
рок тема, издвајају се виолинисти Најџел Кенеди (Kennedy) и Немања Радуловић, који не презају од тога да учествују у светским спектаклима у којима долази до изражаја њихово уметничко-извођачко мајсторство. Пре њих то су чинили великани оперске сцене Павароти (L. Pavarotti), Доминго (P. Domingo) и Kapepac (J. Carreras) (Božilović, 2006: 229-230). С друге стране, има много примера у којима ремек-дела из сфере тзв. популарне уметности (понајвише филма, музике и ликовног стваралаштва) губе на комуникативности са широком публиком због компликованости њихове естетске форме. ${ }^{7}$

Неки теоретичари, попут Џона Фиска (Fiske), популарну културу сматрају културом која заслужује третман озбиљног и прогресивног. Он ову културу види као „поприште борбе“ на коме се води беспоштедни рат између сила моћи и доминације, с једне, и „свакодневног отпора“ који долази са стране популарних стваралаца и публике, с друге стране. Насупрот активности и прогресу, виталности и енергији популарног стоји масовна култура која производи покорну, пасивну масу људи, скуп атомизованих појединаца одвојених од властитих положаја у друштвеној структури и несвесних своје класне свести (Fisk, 2001: 29). С друге стране побуне и непристајања налази се маса потпуно обесправљених и беспомоћних. Супротно прогресу и друштвеној промени којој тежи популарна култура стоји масовна култура која се производи индустријски и која бива наручена „одозго“. Фискову манихејску теорију која популарну културу не третира као потрошњу, већ као ,активан процес стварања и преношења значења и задовољстава унутар одређеног друштвеног система“" (Fisk, 2001: 31) критикују и они „с лева“, као и они „с десна“. Типична је критика Џима Мекгуигана (McGuigan), који устаје против „културног популизма“ Фиска, његовог некритичког величања популарног и смештања истог у опозиционе токове друштва. По Мекгуигановом мишљењу, ту се ради о крајњем симплификовању популарне културе и њених вредности и беспримерном величању публике, нарочито у оквирима савременог капиталистичког козумеризма. На крају: јаз између „популарне“ и „масовне“ културе, код Фиска је коначно затворен без икакве преостале напетости (Mekguigan, 2012: 350).

Проблем форме, који представља једну од централних категорија естетике, везује се за кључна естетичка питања: уметнички лепо и естетско искуство, са једне стране, и продукцију и рецепцију уметности, са друге. Пошто су прва

\footnotetext{
${ }^{7}$ Рецимо, неке композиције тандема Ленон/Lennon-Макартни/McCartney са албума Битлса Revolver, а такође и група Emerson, Lake and Palmer, Pink Floyd, Тул (Tool) и других. Њима се, примерице, могу прикључити филмска ремек-дела Бергмана (I. Bergman), Антонионија (M. Antonioni) и Куросаве (A. Kurosawa).
} 
питања апсолвирана, преостаје разматрање питања производње и пријема естетских порука у домену популарне уметности. Проблем односа производње и стваралаштва у уметничким делима која припадају „ултралакој“ индустрији покушавао је да разреши Едгар Морен (Morin) већ у својој првој свесци Духа времена. Он је, чини се, нашао компромисно решење у томе што је идентификовао „индивидуализоване јединице“ у делима која су, попут филма, стварана по стандардним рецептима (љубавни заплет, happy end). Исти је случај и са свим другим областима популарне културе и уметности у којима постоји потрага за нечим што је оригинално, индивидуално и јединствено. Културна индустрија (од које популарна култура, чак и да хоће, не може да побегне) треба непрестано да премошћује основну противречност која постоји између њене бирократизовано-стандардизоване структуре и оригиналности производа који мора да испоручи. Разрешење проблема, дакле, налази се у помирењу два основна антитетичка пара: бирократија - инвенција, стандард - индивидуалност. Та могућност, пише Морен, почива у самој структури имагинарног. У најбољем случају овде ускаче инвенција, која не дозвољава производњи да угуши стиваралашӣво. Противречност инвенција - стандардизација је механизам за прилагођавање публици и за прилагођавање публике њој.

„Управо постојање ове противречности дозвољава да се схвати тај огромни стереотипизирани свет у филму, шансони, новинарству, радију, с једне стране, а, с друге - та стална инвенција на филму, у шансони, но-

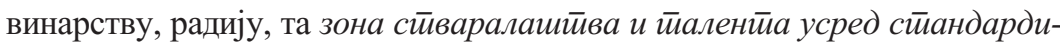
зованої конформизма. Јер индустријализована култура у себе укључује Бресоне и Брасенсе, Фокнере и Велсе, понекад их гушећи, понекад их развијајући“ (Moren, 1979: 31).

Цитирани став Едгара Морена може се актуелизовати тако што ће се поменутим медијима масовне/популарне културе придружити данашњи дигитализовани и технолошки усавршени медији (компјутери и разне електронске мреже), као и најновији правци поп и рок музике (реп, рејв, хаус, ворлд мјузик). Такође, уз поменуте ауторе прошлога века данас се сасвим слободно могу придодати имена нових музичара, списатеља и филмских режисера: Алише Киз (Keys) и Ејми Вајнхаус (Winehouse), Тонија Парсонса (Parsons) и Ника Хорнбија (Hornby), Мартина Скорсезеа (Scorsese), Дејвида Линча (Lynch) и Tima Bartona (Burton). Сви они су већ познатим уметничким стандардима придодавали оригиналну и препознатљиву стваралачку ноту. 
Друштвено-економски односи који од уметничког дела стварају робу, сам естетски акт претварају у произвођење робе, а доживљаваоца у конзумента. Занимљиво је да потрошачку спиралу homo consumericusa у фази хиперпотрошачког друштва више не покрећу толико жеље за друштвеном репрезентацијом колико жеља за управљањем самим собом (Lipovetsky, 2008: 32). Комерцијализација уметничких производа, тежећи да кроји дела према укусу публике - прекраја, у ствари, сам тај укус. Естетски доживљај све чешће бива замењен актом забављања. Таквим приступом ствара се једна униформна слика света која погодује владајућој структури друштва (Ranković, 1996: 237). Замењивање естетских категорија публике (доживљавалац) економским (конзумент) представља тамну страну савремене популарне културе, али постоји и она оптимистичкија варијанта у којој су реципијенти тих дела активни судионици који узимају учешће и у самом чину стварања. Захваљујући ауиеенииччној иниееракиији, популарна уметност подсећа на набујалу реку чији је ток непредвидив и не дв се зауставити.

\section{Звезде као комуникатори}

Комуникација са делима уметнички популарног разликује се од комуникације сериозних уметничких дела и по уделу „звезда“ филма (популарне литературе, музике) у општењу са публиком. Стварање звезда популарне културе јесте комерцијални подухват, а њихови ликови конструисани су по процедурама које дизајнира културна индустрија. Индустријска производња звезда организована је по принципима производње свих осталих роба које се раде конфекцијски, као на покретној траци. О производњи имиџа звезда, посебно филмских, написане су многе књиге, у којима се могу пратити развојни путеви и различити начини афирмације личности уметника, срачунати превасходно на комерцијални ефекат крајњег производа - филма, носача звука (грамофонска плоча, компакт диск, видеотрака) и свега осталог што плени пажњу масовне публике (Morin, 1957; Dyer, 1998). Због свега тога се познати комуникациони ланац, оличен у тријади аутор - дело - публика треба проширити тако што ће уз аутора као уметничког ствараоца и комуникатора одсад стајати звезда, а потом продуцент и канал трансмисије или преношења поруке. У популарној култури имиџ звезда је пресудан чинилац и зато он представља незаобилазну карику у процесу комуникације.

Звезде популарне културе јесу активни фактори комуникације. Њихов имиџ који се огледа у начину представљања осмишљен је на начин којим се може оставити повољан утисак на публику. Репутација звезде зависи од њеног 
имиџа, а он се не ствара увек са реалном ситуацијом него и у складу са идеализованом сликом створеном у јавности. Као и сви људи, и личности звезда саздане су од свога интимног и јавног ,ја“. Због тога се звезде могу читати као фиктивни ликови, произведени имиџи и конструисане личности (Dyer, 1998: 20). На звезданом небу популарности има много звезда „падалица“ јер популарност је друштвено конструисана. Она зависи од много фактора, физичких и социјалних, и зато је пролазна.

Фиск не пропушта да истакне активни, учеснички, одушевљен и навијачки статус обожавалаца у популарној култури, чије обожавање се одликује двема главним активностима: дискриминацијом и продуктивношћу. Обожаваоци рок звезда учествују активно и продуктивно у друштвеном преношењу значења, повлачећи „оштре линије дискриминације“. Буржоаска дискриминација, по Фиску, подједнако је друштвено одређена, но она то прикрива покушавајући да преко „естетике“ своју праксу учини универзалном и поричући њену класну специфичност. У том смислу, она је мање „поштена“ од популарне дискриминације. У популарној култури одабирање текстова је одабирање друштвених припадности, па обожаваоци уграђују себе у одређену заједницу много експлицитније него код припадника „више“ уметности из редова средње класе.

„Везе између друштвене припадности и културног укуса у популарном обожавању активне су и експлицитне, а дискриминација која у њему постоји следи критеријуме друштвене релевантности, пре него критеријуме естетског квалитета““ (Fisk, 2001: 168).

Некадашње узоре у процесу социјализације и носиоце ауторитета, који су се налазили међу учитељима, васпитачима и знаменитим историјским личностима, данас су замениле филмске и медијске звезде, као и звезде поп и рок музике. Савремени узори оличени су у херојима који представљају моделе за идентификацију. Популарне личности могу да мотивишу и инспиришу друге, који покушавају да их подражавају. Односима између звезда и публике често се приписује религиозна димензија, при чему долази до дивинизације личности из света популарне културе. Спона између религије и обожавања звезда има готово некрофилни карактер, праћен религијским ритуалима. Најупечатљивији пример религиозног односа публике према звезди је популарност Елвиса Преслија (Presley), деценијама после његове смрти. У прилог томе сведочи традиција ходочашћа многобројних обожавалаца и следбеника из целог света на његов гроб у Грејсленду, постојање реликвија и меморабилија, а понајвише искрено веровање да је њихов идол бесмртан (Vukadinović, 2013: 134). Има си- 
јасет примера обожавања звезда поп и рок музике, при чему долази до повезивања личног идентитета са идентитетом звезде. О социјално-психолошким аспектима идентификације и пројекције на филму подробно је писао Морен (Moren, 1967; Moren, 1979), али и многи други савремени аутори (Vidi Omon, Bergala, Mari, Verne, 2006).

У сврху популарисања и промоције филмских глумаца, у Холивуду је направљена тржишна стратегија, општепозната као „систем филмских звезда/Stars system“. Тај систем подразумева стварање публицитета око кључних глумаца, „звезда“, и управљање њиме, ради подстицања тражње за њиховим филмовима (Kuk, 2005: 69). Stars system (систем звезда, култ звезда) осмишљен је тако да холивудској филмској индустрији помогне у превазилажењу проблема са рентабилношћу њених производа. У циљу максималног повећања профита и смањивања трошкова, филмске компаније су увеле стандардизацију производног процеса, као и самих филмова. Рационализација производног процеса спроведена је баш као и у класичној индустрији. Стандардизација је подразумевала различите делотворне активности, попут оријентације на жанрове, али је на крају откривено да су глумачке звезде најсигурнија гаранција успеха. Захваљујући звездама, продуцентима је полазило за руком да тржишну вредност одрже на сталној висини кроз дуже раздобље (Behlin, 2002: 145).

И на том плану, међутим, долазило је до промена јер су и имиџ звезде као и производња филмова везани за одређени историјски и друштвени контекст. Док су у време студио система филмске звезде биле обоготвораване и, мореновски речено, стављане на филмски Олимп (Vidi Moren, 1979: 127-133), са гашењем студија „олимпијци“ су све више претварани у „обичне“ људе. Гламурозна звезда којој је придаван митски статус замењена је приземнијом, реалистичнијом, докучивом. „Приземљивање“ звезда вршено је са намером да се публика осети приближеном својим идолима, тако да некадашњи систием звезда бива замењен обухватнијом кулйуром звезда, која проширује славу на многе мање звезде које се појављују у TV програмима (Stojanović, 2014: 68). Томе је допринела чињеница да је филм изгубио некадашњи митски статус, чиме је нестала магична и хипнотичка тама биоскопске сале. Филм је донекле маргинализован пред обиљем сателитских TV канала и интернет понудом најразличитијих садржаја. У вези са тим, филмски јунаци великог платна уступају место звездама таблоида, теленовела и ријалити шоу-програма (Đorđević, 2015: 212).

У свакој новој звезди, било да је реч о филму, литератури, музици, спорту или политици, Американци су видели наду у испуњење обећаног ,америчког сна“, сажетог у познатом слогану „Преко трња до звезда“ Да нису створене звезде, тај мит остао би мртво слово на папиру. Холивуд са својим звездама 
оживоторио је тај мит и покренуо бескрајну траку производње звезда на свим нивоима културе. Упоредо са рађањем нових звезда долазило је до нових стратификација публике и фанова као опсесивних (фанатичних) обожавалаца популарне културе или неке од медијских личности.

\section{Закључак}

У доба постмодернизма и постмодерне 8 депласирано је говорити о сувише строгим поделама између уметничких врста, постављању граничних зона, то јест демаркационих линија између њих. Криза модерне, укључујући кризу идеје рационализма у другој половини XX века, огласила је и суноврат некада важећих вредности у култури - од науке и уметности до свакодневног живота. Незамисливо је да се у времену мешања жанровских конвенција на пољу уметности, комбиновања медијских формата и релативизовања естетских вредности, данас постављају баријере или подижу зидови између различитих уметничких врста. Посебно је ослабила граница између популарне културе и онога што се некада сматрало високом уметношћу.

Упркос томе, у културолошким студијама и даље су у употреби термини високе (елитне) и популарне културе јер они сведоче о времену владавине одређених вредности и норми у култури. Преко тих појмова социолози долазе до драгоцених закључака о друштву - његовом карактеру, његовој структури, тенденцијама и правцима развоја. На популарну културу не треба гледати (само) као на антипод високој (владајућој, елитној, доминантној) култури. Осим тога што је популарна култура поставила нове стандарде у сфери уметности (боље рећи: оборила и обесмислила старе), између та два облика културе могуће је да данас постоји сарадња, укрштање и међуделовање. Популарно је преузело неке елементе високог, нарочито у појединим, захтевнијим облицима стваралачког израза. С друге стране, популарна култура утицала је на демократизацију стваралаштва тиме што је готово све облике симболичке културе (језик, научно сазнање, уметност) пренела из замишљених недостижних висина у свакодневни живот.

${ }^{8}$ Иако се могу установити прецизне дистинкције између појмова „постмодерна“, „постмодерно“ и „постмодернизам“, већина аутора их користи као синониме. У начелу, под термином постмодерне подразумева се историјска епоха након модерне, док се термини постмодернизам и постмодерно односе на феномене свакодневице или уметности. Док Тери Иглтон (Eagleton), постмодернизам сматра за један облик културе, а посмодернитет узима за један специфичан историјски период, Жан Бодријар (Baudrillard) готово да уопште није у својим радовима користио ту појмовну апаратуру (Maširević, 2011: 23). 
Захваљујући популарној култури, дела уметности (посебно ликовних, филмске и музичке) постају комуникативнија, што ће рећи доступнија свим укусима и свим друштвеним слојевима као њиховим власницима. И по форми (естетика) и по садржајима (комуникација) та дела су, без обзира што се чине баналнијима, ближа духу и сензибилитету савремене публике. Услови за комуникацију са њима нису смештени у институције (школе), већ се они стичу директним путем - учествовањем публике у њиховој продукцији и презентацији. Једноставност изражајних поступака у популарној култури, као и њихова непосредност, доводе до стања које може произвести осећања задовољства и узвишености, једнако као у делима високе културе/уметности. Реципијент садржаја популарне културе има равноправно место и улогу у трианглу уметник - дело - публика. Он је активни судионик уметничке комуникације.

За социологе је битна чињеница да дела популарне културе комуницирају са публиком која је масовна и хетерогена. Данас је читава култура смештена у оквире популарног, а популарног нема ако није прошло кроз медије. Естетска димензија није примарна у популарним садржајима, који морају задовољити и критеријуме забавног, лаког и пријемчивог. Међутим, забавно не искључује естетски озбиљне приступе, који се могу пронаћи у многобројним филмовима, у артистичким приступима кроз разне mixed-medialne форме, као и у композицијама прогресивног и арт рока.

Важну особеност комуникације популарне културе чине такозване звезде (глумци, ведете, певачи, старлете). Звезде су активни чиниоци комуникационог ланца, а њихова популарност је продукт социјалне конструкције. Та популарност налази се у функцији одржавања непрекидног тока комуникације, који подразумева, стварање, одржавање и репродукцију популарног. Филмске и медијске звезде, као и звезде популарне музике су савремени узори, хероји који младима служе као модели за идентификацију. Нови „олимпијци“, за које Морен каже да су намагнетисани и имагинарним и стварним, од средине прошлог столећа доминирају масовном и популарном културом, с тим што су они у нашем веку много ближи и достижнији обичном човеку, па самим тим и пролазнији. У данашње време када се свему и свачему додаје префикс „пост“, и они би се могли назвати пост-олимпијцима. 


\section{ЛИТЕРАТУРА}

Adorno, T. i Horkhajmer M. (2012). Kulturna industrija. U: J. Đorđević, Studije kulture. Zbornik. Beograd: Službeni glasnik, str. 66-100.

Bal, F. (1997). Moć medija. Beograd: Clio.

Bauman, Z. (1973). Culture as Praxis. Boston \& London: Routledge \& Kegan Paul.

Behlin, P. (2002). Film kao roba. Beograd: Zavod za udžbenike i nastavna sredstva.

Benjamin, V. (1974). Umetničko delo u veku svoje tehničke reprodukcije. U: Eseji. Beograd: Nolit, str. $114-150$.

Bortvik, S. i Moj, R. (2010). Popularni muzički žanrovi. Beograd: Clio.

Bourdieu, P. (1984). Distinction: A Social Critique of the Judgement of Taste. Cambridge, Massachusetts: Harvard University Press.

Božilović, N. (2006). Kič kultura. Niš: Zograf.

Božilović, N. (2014). Estetika popularnog. U: Z. M. Jovanović i dr. (prir.), Umetnost i njena uloga u istoriji: između trajnosti i prolaznih -izama posvećen sećanju na prof. dr Miodraga Jovanovića (1932 -2013), Kosovska Mitrovica: Filozofski fakultet u Prištini, str. 49-67.

Debor, G. (2003). Društvo spektakla. Beograd: Porodična biblioteka br. 4, anarhija/blok 45.

Dorfles, G. (1963). Oscilacije ukusa i moderne umjetnosti. Zagreb: Mladost.

Dragićević Šešić, M. (2012). Umetnost i alternativa. Beograd: FDU i Clio.

Dyer, R. (1998). Stars. London: British Film Institute.

Đorđević, J. (2012). Studije kulture. Zbornik. Beograd: Službeni glasnik.

Đorđević, Đ. (2015). Film i tržište: vidovi komercijalizacije savremenog holivudskog filma. Doktorska disertacija (unpublished). Niš: Filozofski fakultet.

Eko, U. (2002). O književnosti. Beograd: Narodna knjiga.

Fisk, Dž. (2001). Popularna kultura. Beograd: Clio.

Fulkinjoni, E. (1980). Civilizacija slike. Beograd: Institut za film.

Gans, H. J. (1999). Popular Culture and High Culture. New York: Basic Books.

Gocić, G. (2012). Endi Vorhol i strategije popa. Beograd: Službeni glasnik.

Gramši, A. (2012). Hegemonija, intelektualci i država. U: J. Đorđević, Studije kulture. Zbornik. Beograd: Službeni glasnik, str. 148-155.

Gronow, J. (2000). Sociologija ukusa. Zagreb: Naklada Jesenski i Turk, Hrvatsko sociološko društvo.

Hauser, A. (1986). Sociologija umjetnosti 2. Zagreb: Školska knjiga.

Hobsbaum, E. (2014). Kraj kulture: Kultura i društvo u XX veku. Beograd: Arhipelag.

Јовановић, С. (2005). Кулииурни образач. Београд: Стубови културе.

Kloskovska, A. (2001). Sociologija kulture. Beograd: Čigoja štampa.

Kon, Ž. (2001). Estetika komunikacije. Beograd: Clio.

Kuk, D. A. (2005). Istorija filma I. Beograd: Clio.

Lipovetsky, G. (2008). Paradoksalna sreća: Ogled o hiperpotrošačkom društvu. Zagreb: Antibarbarus.

Macan, E. (1997). Rocking the Classics: English Progressive Rock and the Counterculture. Oxford: Oxford University Press. 
Maširević, Lj. (2011). Postmoderna teorija i film na primeru kinematografije Kventina Tarantina. Beograd: Čigoja štampa, Institut za sociološka istraživanja Filozofskog fakulteta u Beogradu.

Maze, K. (2008). Bezgranična zabava: Uspon masovne kulture 1850-1970. Beograd: Službeni glasnik.

Mekguigan, Dž. (2012). Putevi kulturnog populizma. U: J. Đorđević, Studije kulture. Zbornik. Beograd: Službeni glasnik, str. 347-359.

Moren, E. (1967). Film ili čovek iz mašte. Beograd: Institut za film.

Moren, Edgar (1979). Duh vremena 1. Beograd: BIGZ.

Morin, E. (1957). Les stars. Paris: E?ditions du Seuil.

Omon, Ž., Bergala, A., Mari, M., Verne, M. (2006). Estetika filma. Beograd: Clio.

Ranković, M. (1996). Opšta sociologija umetnosti. Beograd: Zavod za udžbenike i nastavna sredstva.

Shils, E. (1961). Mass Society and Its Culture. In N. Jacobs (ed.), Culture for the Millions, New York: D. Van Nostrand Comp, pp. 81-87.

Stojanović, S. (2014). Industrija kulture, savremene zvezde i dramaturški model komunikacije. Doktorska disertacija (unpublished). Beograd: Fakultet političkih nauka.

Torg, A. (2002). Pop i rok muzika. Beograd: Clio.

Vot, J. (1990). Čitalačka publika i nastanak romana. U: S. Petrović (prir.), Sociologija književnos$t i$, Beograd: Zavod za udžbenike i nastavna sredstva, str. 217-231.

Vukadinović, M. (2013). Zvezde supermarket kulture: medijska slava u potrošačkom društvu. Beograd: Clio.

Жикић, Б. (2012). Популарна култура: надкултурна комуникација. Ейноанииройолошки йроблеми, св. 2: 315-342. 
Nikola Božilović

Summary

University of Niš

Faculty of Philosophy

\section{COMMUNICATION OF THE POPULAR}

The article deals with the problems of the communication of popular culture. It considers the more specialized meaning of popular culture, which primarily encompasses the works of artistic forms which have a popular character - easily understandable and entertaining contents and wide audience. The aesthetic communication of the popular through popular literature, film, pop and rock music is examined.

The paper is divided into three parts. The first parts deals with the aesthetics of the communication of popular culture. It contains the analysis of the major formal-aesthetic procedures embedded in the creative expression of the popular. In the part which is dedicated to social aspects of the communication of popular art, the author examines the industrial, market and commercial principles upon which this whole culture is based. It is a time of new technologies and mass consumption, which represent, in the words of Eric Hobsbawm, a "cultural landscape" that has transformed the manner in which a new audience experiences the artistic.

Finally, popular culture stars are observed as communicators. The author adds them as a new, even crucial, link in the already known chain of communication comprising the author, the work and the audience. Stars (film, popular music) are active factors of communication as well as its bearers. They are the intermediaries through which the audience establishes relationships with the authors (writers, directors, composers) and the works in which those stars appear. Stars as "new Olympians" (Morin) are, indeed, another significant category that distinguishes the communication of popular culture.

Key words: popular culture, communication, elite culture, aesthetics, cultural industry, consumer society, stars. 